\title{
Linear and whorled nevoid hypermelanosis with hyper lgE syndrome
}

\section{Podłużna i wirowata znamieniopodobna hipermelanoza z współwystępowaniem zespołu hiper-lgE}

Joanna Sieniawska', Aleksandra Lesiak', Wioletta Pietruszewska², Anna Woźniacka', Joanna Narbutt'

'Department of Dermatology and Venereology, Medical University of Lodz, Lodz, Poland

2Department of Otolaryngology, Medical University of Lodz, Lodz, Poland

Przegl Dermatol 2015, 102, 19-22

DOI: 10.5 | |4/dr.2015.49483

KEY WORDS:

hyperpigmentation, lines of Blaschko, congenital defects.

SŁOWA KLUCZOWE:

hiperpigmentacja, linie Blaschko, defekty genetyczne.
ADDRESS FOR CORRESPONDENCE:

Aleksandra Lesiak MD, PhD

Department of Dermatology

and Venereology

Medical University of Lodz

5 Krzemieniecka St

94-017 Lodz, Poland

Phone: +48 426867981

E-mail: lesiak_ola@interia.pl

\section{ABSTRACT}

Introduction. Linear and whorled nevoid hypermelanosis (LWNH) is a disorder of pigmentation characterized by macular hyperpigmentation following the Blaschko lines. Only 50 cases of LWNH have been described so far. Linear and whorled nevoid hypermelanosis may be associated with congenital defects. Underlying chromosomal mosaicism has been demonstrated in only a few published cases. Diagnosis is based on characteristic clinical and histopathological findings.

Objective. Presentation of the first Polish case of LWNH.

Case report. We present a 29-year old Caucasian woman with streaks of reticulate hyperpigmented macules arranged in a whorled pattern over the trunk and extremities. Histopathology showed hyperpigmentation of the epidermal basal layer and prominent melanocytes, without pigment incontinence. Based on clinical and histopathological findings the diagnosis of LWNH was established. Additionally hyper IgE syndrome has been diagnosed in the patient.

Conclusions. In LWNH the therapeutic challenge is the diagnosis and treatment of comorbidities; otherwise it may cause a serious threat to the patient's health.

\section{STRESZCZENIE}

Wprowadzenie. Podłużna i wirowata znamieniopodobna hipermelanoza (ang. linear and whorled nevoid hypermelanosis with hyper IgE syndrome - LWNH) jest zaburzeniem pigmentacji skóry charakteryzującym się występowaniem przebarwień ułożonych wzdłuż linii Blaschko. Do tej pory opisano ok. 50 przypadków tej choroby. Schorzenie może współistnieć z licznymi wadami wrodzonymi. W kilku opisanych przypadkach stwierdzono występowanie mozaikowatości chromosomalnej. Rozpoznanie ustala się na podstawie charakterystycznego przebiegu klinicznego i badania histopatologicznego.

Cel pracy. Przedstawienie pierwszego w Polsce przypadku LWNH.

Opis przypadku. Prezentujemy przypadek 29-letniej kobiety z ogniskami hiperpigmentacji o układzie linijnym i wirowym zlokalizowanymi na skórze tułowia i kończyn. W badaniu histopatologicznym wycinka skóry stwierdzono hiperpigmentację w podstawnej warstwie naskórka oraz okołonaczyniowe skupienia komórek limfoidalnych z obecnością melanofagów. Na podstawie badania histopatologicznego i obrazu kli- 
nicznego ustalono rozpoznanie LWNH. Ponadto u pacjentki potwierdzono współwystępowanie zespołu hiper-IgE.

Wnioski. Istotnym problemem w przypadkach LWNH jest diagnostyka i leczenie chorób towarzyszących, które z nią współistnieją i mogą stanowić poważne zagrożenie dla zdrowia pacjenta.

\section{INTRODUCTION}

Linear and whorled nevoid hypermelanosis (LWNH) is a pigmentation disorder characterized by macular hyperpigmentation following the lines of Blaschko. It was first reported by Kalter et al. in 1988 [1]. Only 50 cases of LWNH have been described so far, particularly in individuals with high skin phototype. The first skin lesions appear in infancy, usually in the first weeks of life, and gradually worsen. Pigmentations are not preceded by any other skin changes. Stabilization of skin lesions usually occurs after 2-3 years [1-4]. Histopathologically it shows only epidermal melanosis [1, 5-7]. Linear and whorled nevoid hypermelanosis may be associated with congenital defects relating to the nervous, cardiovascular and skeletal systems and ocular anomalies [8-12]. The coexistence of hemiatrophy, Axenfeld-Rieger syndrome, inflammatory linear verrucous epidermal nevus (ILVEN), ichthyosis vulgaris and cerebrovascular malformations is also described [13-16].

Underlying chromosomal mosaicism has been demonstrated in only a few published cases (mosaic trisomy 7, 18 or 20) [17-19]. Hong et al. [20] described inversion of chromosome 9 corresponding with LWNH. Furthermore there are also described cases of the occurrence of LWNH inherited in subsequent generations [5-21]. The differential diagnosis includes incontinentia pigmenti, epidermal nevi, hypomelanosis of Ito, Goltz syndrome and Moulin syndrome [2226]. Diagnosis is based on characteristic clinical and histopathological examination. Dermoscopy shows linear or circular streak-like pigmentations arranged in a parallel manner [27]. However, the rare occurrence of the entity causes diagnostic problems.

\section{OBJECTIVE}

We present a case of LWNH, which, according to our knowledge, is the first case reported in Polish literature.

\section{CASE REPORT}

We present a case of a 29-year-old Caucasian woman with second skin phototype with progres- sively increasing streaks of reticulate hyperpigmented macules. The lesions were arranged in a whorled pattern over the trunk and extremities and appeared in the first years of life (Fig. 1 A, B). There was no history of any preceding bullous or verrucous eruption. She was treated in the otolaryngology department due to frequent bacterial and fungal infection of the upper respiratory tract. Moreover, dental defects and aphthae in the oral cavity were observed (Fig. 2). Dermoscopy examination showed linear streaklike pigmentations arranged in a parallel manner (Fig. 3). Histopathological examination of skin lesions revealed hyperpigmentation of the epidermal basal layer and prominent melanocytes, without pigment incontinence. Based on clinical and histopathological findings the diagnosis of LWNH was established. In addition, laboratory tests showed a high level of $\operatorname{IgE}(2882 \mathrm{kU} / \mathrm{l})$ and defects of innate and acquired immunity. The diagnosis of hyper IgE syndrome was confirmed.

\section{DISCUSSION}

We present this case because LWNH is a very rare entity especially among fair skinned subjects. So far only a few cases of the disease have been published. In reported cases association of LWNH with many congenital defects was observed, and in our case LWNH coexisted with immunological defects and hyper IgE syndrome [28]. In the differential diagnosis incontinentia pigmenti, epidermal nevi, hypomelanosis of Ito, Goltz syndrome and Moulin syndrome have to be considered [24-26, 29]. In hypomelanosis of Ito the skin symptoms are associated with malformations of the skeletal system, central nervous system, teeth and hair. A significant percentage of patients have epilepsy, and often mental disorders are found [23]. The skin lesions in incontinentia pigmenti appear after birth, are diverse, and the disease is characterized by successive phases. Initially there appear erythema and blisters, which are converted to verrucous lesions. The next phase is characterized by formation of foci of hyperpigmentations and hypopigmentations. The disease is linked to chromosome $X$, usually lethal to the male [22]. In 

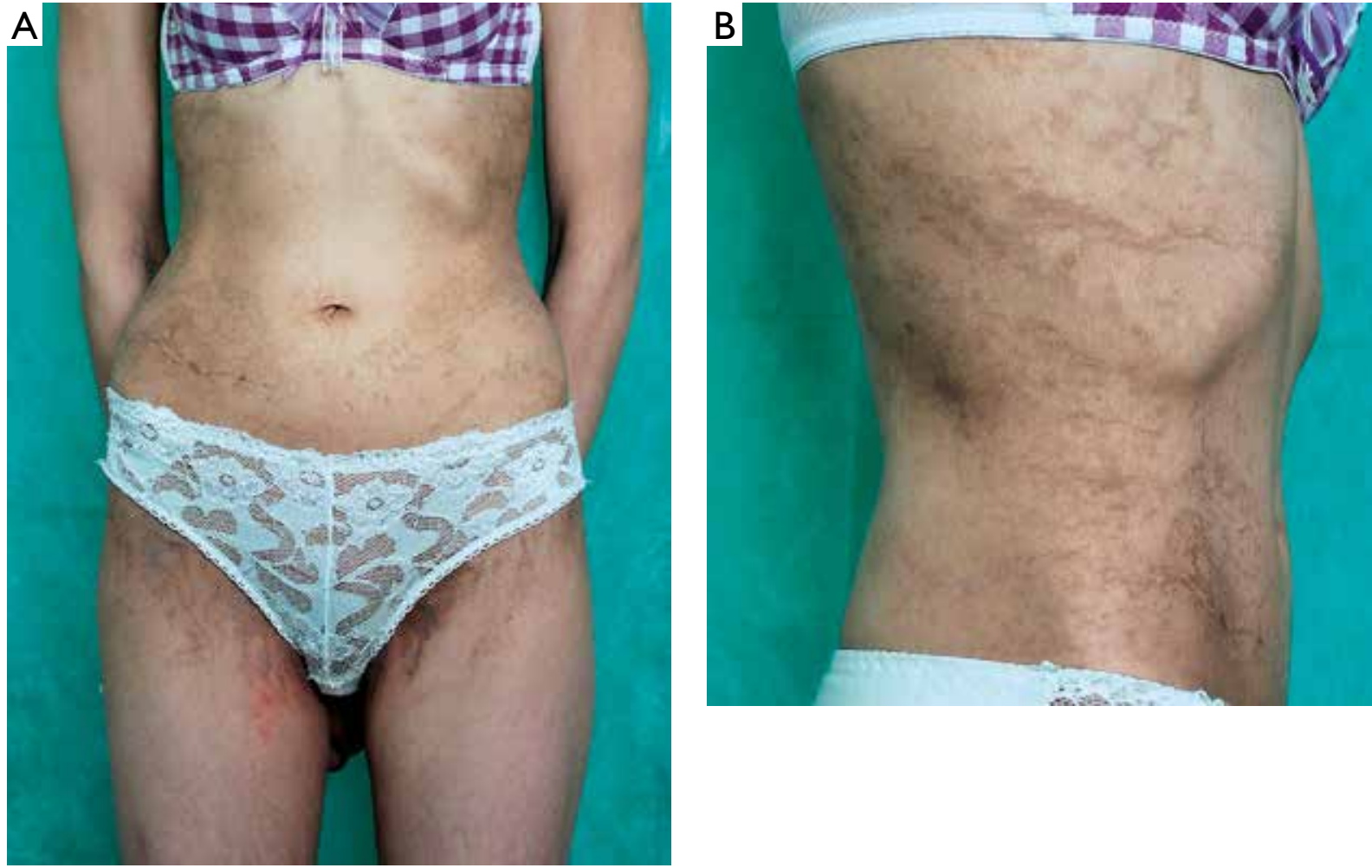

Figure I A, B. Skin lesions arranged in a whorled pattern over the trunk and extremities

Rycina I A, B. Zmiany skórne ułożone wirowato na tułowiu i kończynach

the case of epidermal nevus skin lesions are usually congenital. Initially there appear outbreaks of hyperpigmentation, which later take the verrucous form. Most lesions are linear and do not exceed the central line of the body [24]. In Goltz syndrome, pigmentations are accompanied by other skin changes such as: verrucous papillomas, alopecia, abnormal nail structure, hyperhidrosis, and hyperkeratosis of hands and feet. Comorbidities involved are serious [26].

Moulin syndrome is characterized by the presence of soft linear atrophic, hyperpigmented lesions. Skin changes are usually one-sided, and eruptions occupy the trunk [25]. In our patient, clinical, dermoscopic and histopathological examination showed characteristic features for $\mathrm{LWNH}$, in line with other reported cases [1-16, 27]. Treatment of LWNH does not give satisfactory results. Therapeutic options are limited. The therapy uses chemical peels and $2 \%$ hydroquinone [30]. One case was treated with a medium-depth chemical peel regimen using 70\% glycolic acid and 35\% trichloroacetic acid with no benefit [7]. Our patient did not give informed consent for any topical treatment of her skin lesions.

\section{CONCLUSIONS}

In the literature there has not been described coexistence of LWNH with hyper IgE syndrome.

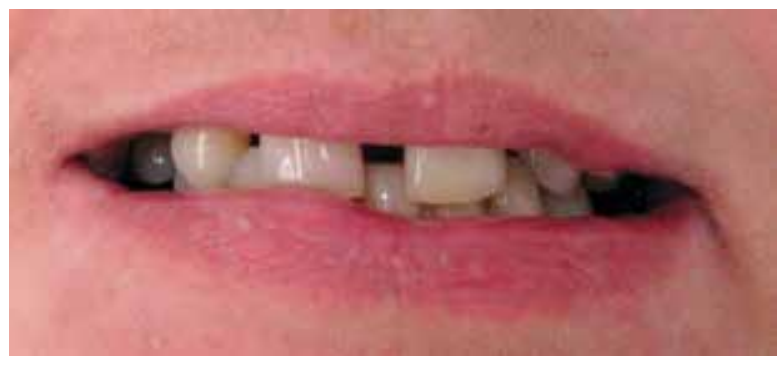

Figure 2. Dental defects

Rycina 2. Defekty zębów

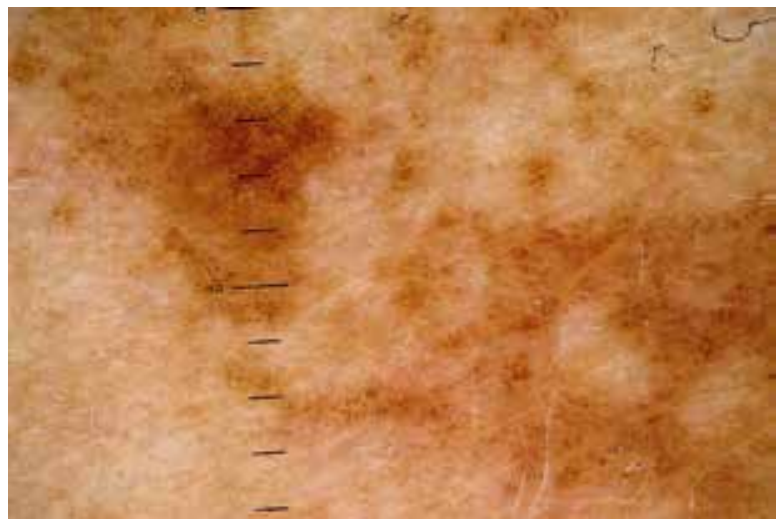

Figure 3. Dermoscopy examination - linear streak-like pigmentations arranged in a parallel manner

Rycina 3. Badanie dermoskopowe. Linijne, pasmowate przebarwienia ułożone równolegle 
Since LWNH is often associated with the presence of genetic defects and malformations, the most challenging is the diagnosis and treatment of comorbidities; otherwise it may cause a serious threat to the patient's health. According to our knowledge, the presented case is the first case of LWNH in Poland.

\section{ACKNOWLEDGMENTS}

The study was funded by the Medical University of Lodz, project no. 503/1-152-01/503-01.

\section{References}

1. Kalter D.C., Griffiths W.A., Atherton D.J.: Linear and whorled neviod hypermelanosis. J Am Acad Dermatol 1988, 19, 1037-1044.

2. Mendiratta V., Sharma R.C., Arya L., Sardana K.: Linear and whorled neviod hypermelanosis. J Dermatol 2001, 28, 58-59.

3. Alvarez J., Peteiro C., Toribio J.: Linear and whorled neviod hypermelanosis. Pediatr Dermatol 1993, 10, 156-158.

4. Kanwar A.J., Dhar S., Ghosh S., Kaur S.: Linear and whorled nevoid hypermelanosis. Int J Dermatol 1993, 32, 385-386.

5. Akiyama M., Aranami A., Sasaki Y., Ebihara T., Sugiura M.: Familial linear and whorled nevoid hypermelanosis. J Am Acad Dermatol 1994, 30, 831-833.

6. Kubota Y.,Shimura Y.,Shimada S., Tamaki K., Amamiya S.: Linear and whorled neviod hypermelanosis in a child with chromosomal mosaicism. Int J Dermatol 1992, 31, 345-347.

7. Yuksek J., Sezer E., Erbil A.H., Arca E., Taştan H.B, Kurumlu Z., et al.: Linear and whorled nevoid hypermelanosis. Dermatol Online J 2007, 13, 23.

8. Hassab-El-Naby H.M., Alsaleh Q.A., Fathallah M.A.: Linear and whorled neviod hypermelanosis: report of a case associated with cerebral palsy. Pediatr Dermatol 1996, 13, 148-150.

9. Schepis C., Alberti A., Siragusa M., Romano C.: Progressive cribriform and zosteriform hyperpigmentation: the late-onset feature of linear and whorled nevoid hypermelanosis associated with congenital neurological, skeletal and cutaneous anomalies. Dermatology 1999, 199, 72-73.

10. Alrobaee A.A., Alsaif F.: Linear and whorled nevoid hypermelanosis associated with developmental delay and generalized convulsions. Int J Dermatol 2004, 43, 145-147.

11. Schepis C., Siragusa M., Alberti A., Cavallari V.: Linear and whorled nevoid hypermelanosis in a boy with mental retardation and congenital defects. Int J Dermatol 1996, 35 654-655.

12. Alimurung F.M., Lapenas D., Willis I., Lang P.: Zebra-like hyperpigmentation in an infant with multiple congenital defects. Arch Dermatol 1979, 115, 878-891.

13. Jain P., Chakrabarty B., Gulati S.: Linear and whorled nevoid hypermelanosis with hemiatrophy. Indian Pediatr 2012, 49, 936.

Received: 4 XI 2014 r.

Accepted: 11 XII 2014 r.
14. Llamas-Velasco M., Eguren C., Arranz E., Renedo M., de Argila D., Garcia-Diez A.: Linear and whorled nevoid hypermelanosis and Axenfeld-Rieger anomaly: a novel association. Acta Derm Venereol 2010, 90, 317-318.

15. Mégarbané A., Vabres P., Slaba S., Smahi A., Loeys B., Okais N.: Linear and whorled nevoid hypermelanosis with bilateral giant cerebral aneurysms. Am J Med Genet 2002, 112, 95-98.

16. Lu Y., Zhu W.Y.: Linear and whorled nevoid hypermelanosis complicated with inflammatory linear verrucous epidermal nevus and ichthyosis vulgaris. J Dermatol 2007, 34, 765-768.

17. Verghese S., Newlin A., Miller M., Burton B.K.: Mosaic trisomy 7 in a patient with pigmentary abnormalities. Am J Med Genet 1999, 87, 371-374.

18. Komine M., Hino M., Shiina M., Kanazawa I., Soma Y., Tamaki K.: Linear and whorled naevoid hypermelanosis: a case with systemic involvement and trisomy 18 mosaicism. Br J Dermatol 2002, 146, 500-502.

19. Hartmann A., Hofmann U.B., Hoehn H., Broecker E.B., Hamm H.: Postnatal confirmation of prenatally diagnosed trisomy 20 mosaicism in a patient with linear and whorled nevoid hypermelanosis. Pediatr Dermatol 2004, 21, 636-641.

20. Hong S.P., Ahn S.Y., Lee W.S.: Linear and whorled nevoid hypermelanosis: unique clinical presentations and their possible association with chromosomal abnormality inv(9). Arch Dermatol 2008, 144, 415-416.

21. Metta A.K., Ramachandra S., Sadath N., Manupati S.: Linear and whorled nevoid hypermelanosis in three successive generations. Indian J Dermatol Venereol Leprol 2011, 77, 403.

22. Emre S., Firat Y., Güngör S., Firat A.K., Karincaoğlu Y.: Incontinentia pigmenti: a case report and literature review. J Pediatr 2009, 51, 190-194.

23. Ruiz-Maldonado R., Toussaint S., Tamayo L., Laterza A., del Castillo V.: Hypomelanosis of Ito: diagnostic criteria and report of 41 cases. Pediatr Dermatol 1992, 9, 1-10.

24. Kim R., Marmon S., Kaplan J., Kamino H., Pomeranz M.K.: Verrucous epidermal nevus. Dermatol Online J 2013, 19, 20707.

25. Rompel R., Mischke A.L., Lagner C., Happle R.: Linear atrophoderma of Moulin. Eur J Dermatol 2000, 10, 611-613.

26. Goltz R.W.: Focal dermal hypoplasia syndrome. An update. Arch Dermatol 1992, 128, 1108-1111.

27. Ertam I., Turk B.G., Urkmez A., Kazandi A., Ozdemir F.: Linear and whorled nevoid hypermelanosis: dermatoscopic features. J Am Acad Dermatol 2009, 60, 328-331.

28. Yong P.F., Freeman A.F., Engelhardt K.R., Holland S., Puck J.M., Grimbacher B.: An update on the hyper-IgE syndromes. Arthritis Res Ther 2012, 14, 228.

29. Nehal K.S., PeBenito R., Orlow S.J.: Analysis of 54 cases of hypopigmentation and hyperpigmentation along the lines of Blaschko. Arch Dermatol 1996, 132, 1167-1170.

30. Mehta V., Vasanth V., Balachandran C., Mathew M.: Linear and whorled nevoid hypermelanosis. Int J Dermatol 2011, 50, 491-492. 